
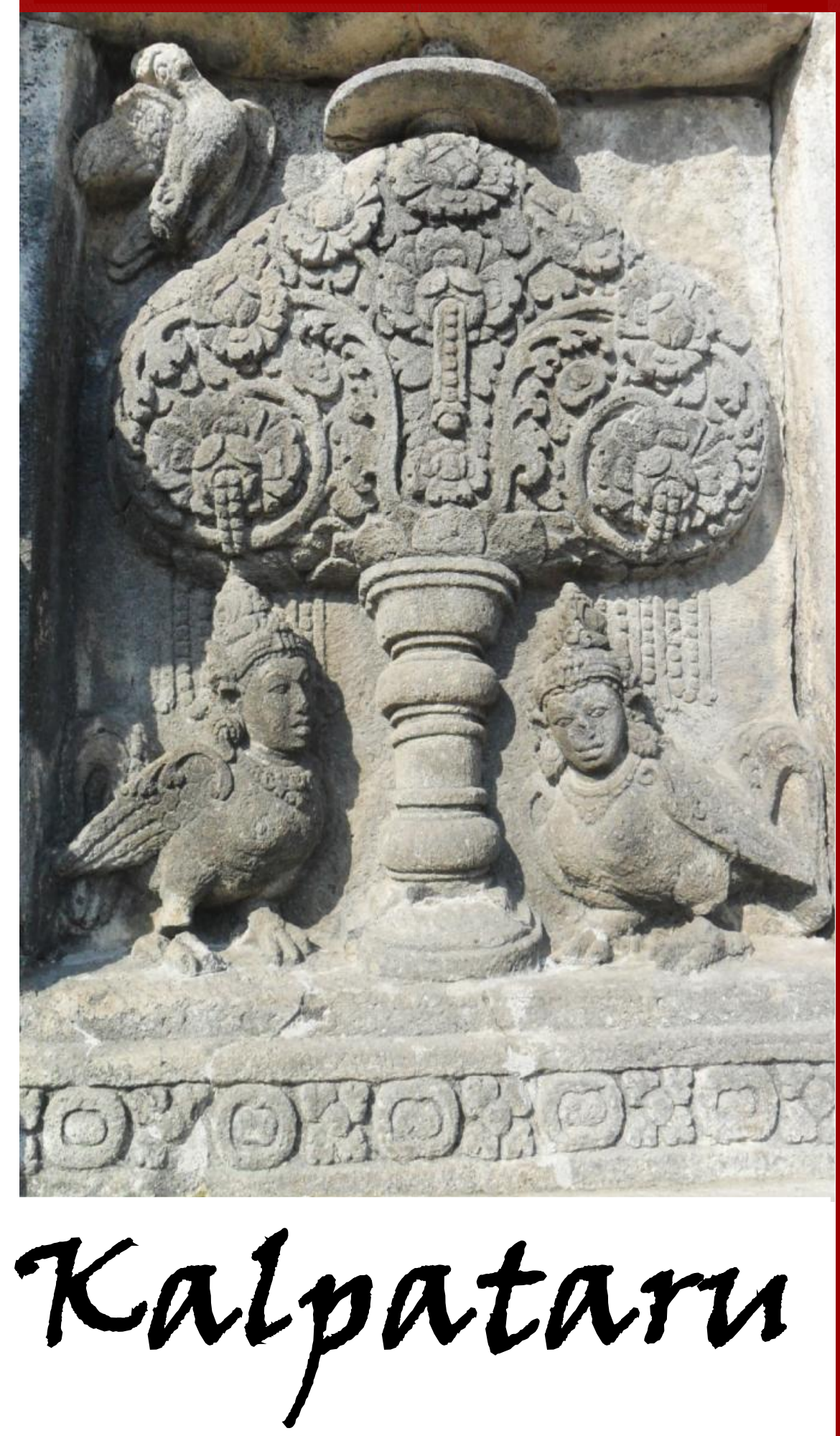

JURNAL SEJARAH DAN PEMBELAJARAN SEJARAH

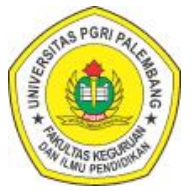

Program Studi Pendidikan Sejarah Jurusan Pendidikan IPS

Fakultas Keguruan dan IImu Pendidikan Universitas Persatuan Guru Republik Indonesia Palembang
Kajian Tata Ruang Lukisan Dinding Pada Batu Balai di Desa Tegur Wangi Lama Kota Pagaralam Sebagai Sumber Pembelajaran Sejarah

Muhammad Randi Saputra, H. Rudi Asri

Nilai Sejarah Toponim di Kecamatan Bukit Kecil Kota Palembang Sebagai Sumber Pembelajaran Sejarah di SMP Negeri 33 Palembang

Dedi Berianto

Upaya Meningkatkan Kualitas Pembelajaran Sejarah Melalui Penerapan Outdoor Learning Berbasis Inkuiri di SMA Muhammadiyah 1 Palembang

Arman, Fatmah

Senjang: Sejarah Tradisi Lisan Masyarakat Musi Banyuasin

Brian Apriadi, Eva Dina Chairunisa

Peningkatan Hasil Belajar dan Aktifitas Siswa Melalui Model Pembelajaran Discovery Learning di SMA Negeri 8 Palembang

Sri Mulyati, Nurhayati Dina, Apriana

Jenis-Jenis Peninggalan Megalit di Desa Tanjung Aro Sebagai Sumber Pembelajaran Sejarah di Kelas X SMA Muhammadiyah 3 Palembang Tahun Ajaran 2017/2018

Lita Sepriani

Persepsi Siswa Terhadap Penggunaan Media Film Dokumenter Materi Kehidupan Manusia Purba Pada Mata Pelajaran Sejarah di SMK Negeri 6 Palembang M. Edo Nuryana

Sejarah Tulung Selapan Sebagai Sumber Penulisan Sejarah Lokal Ogan Komering Ilir

Muhamad Idris

Pengaruh Model Pembelajaran Explicit Instruction Terhadap Hasil Belajar Siswa Pada Mata Pelajaran Sejarah di Sekolah Menengah Atas Negeri 1 Gelumbang Ramoni Handayani

Pengaruh Penggunaan Media Film Dokumenter Terhadap Hasil Belajar Siswa Pada Mata Pelajaran Sejarah di Sekolah Menengah Atas Sriguna Palembang Vina Pratiwi 


\section{Kalpataru}

Jurnal Sejarah dan Pembelajaran Sejarah

Volume 4, Nomor 2, Desember 2018

Penanggung Jawab

Dr. Dessy Wardiah, M.Pd.

Ketua Dewan Redaksi

Drs. Sukardi, M.Pd.

\section{Penyunting Pelaksana}

Muhamad Idris, M.Pd.

Eva Dina Chairunisa, M.Pd.

Jeki Sepriady, S.Pd.

Dr. Tahrun, M.Pd.

Drs. Supriyanto, M.Hum.

Dra. Retno Purwati, M.Hum.

Dr. Nor Huda Ali, M.Ag., M.A.

Budi Agung Sudarman, S.S., M.Pd.

Dr. Purmansyah, M.A.

\section{Penyunting Ahli}

(Universitas PGRI Palembang)

(Universitas Sriwijaya Palembang)

(Balai Arkeologi Sumatera Selatan)

(Masyarakat Sejarawan Indonesia Sumsel)

(Balai Bahasa Provinsi Sumatera Selatan)

(Universitas Muhammadiyah Palembang)

\section{Alamat Redaksi}

Program Studi Pendidikan Sejarah

Jurusan Pendidikan IImu Pengetahuan Sosial

Fakultas Keguruan dan IImu Pendidikan Universitas PGRI Palembang

Telp. 0711-510043

Email: jurnalkalpatarusejarah@gmail.com

Website: https://jurnal.univpgri-palembang.ac.id/index.php/Kalpa 


\section{Kalpataru}

\author{
JURNAL SEJARAH DAN
}

PEMBELAJARAN SEJARAH

Terbit dua kali setahun pada Juli dan Desember

Diterbitkan oleh:

Program Studi Pendidikan Sejarah Jurusan Pendidikan IPS

Fakultas Keguruan dan IImu Pendidikan Universitas PGRI Palembang

\section{Gambar Cover: \\ Pohon Kalpataru \\ Candi Prambanan}

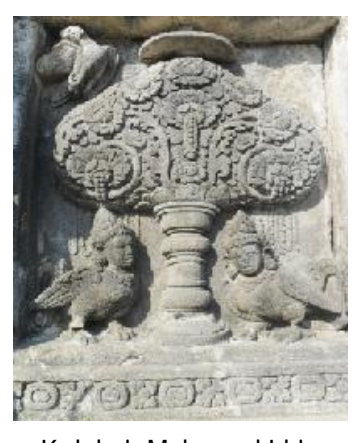

Koleksi: Muhamad Idris

\section{DAFTAR ISI}

Kajian Tata Ruang Lukisan Dinding Pada Batu Balai di Desa Tegur Wangi Lama Kota Pagaralam Sebagai Sumber Pembelajaran Sejarah

Muhammad Randi Saputra, H. Rudi Asri. $.89-98$

Nilai Sejarah Toponim di Kecamatan Bukit Kecil Kota Palembang Sebagai Sumber Pembelajaran Sejarah di SMP Negeri 33 Palembang

Dedi Berianto. 99-110

Upaya Meningkatkan Kualitas Pembelajaran Sejarah Melalui Penerapan Outdoor Learning Berbasis Inkuiri di SMA Muhammadiyah 1 Palembang

Arman, Fatmah.

Senjang: Sejarah Tradisi Lisan Masyarakat Musi Banyuasin

Brian Apriadi, Eva Dina Chairunisa

Peningkatan Hasil Belajar dan Aktifitas Siswa Melalui Model Pembelajaran Discovery Learning di SMA Negeri 8 Palembang

Sri Mulyati, Nurhayati Dina, Apriana.

Jenis-Jenis Peninggalan Megalit di Desa Tanjung Aro

Sebagai Sumber Pembelajaran Sejarah di Kelas X SMA

Muhammadiyah 3 Palembang Tahun Ajaran 2017/2018

Lita Sepriani..

Persepsi Siswa Terhadap Penggunaan Media Film Dokumenter Materi Kehidupan Manusia Purba Pada Mata Pelajaran Sejarah di SMK Negeri 6 Palembang M. Edo Nuryana.

Sejarah Tulung Selapan Sebagai Sumber Penulisan Sejarah Lokal Ogan Komering Ilir Muhamad Idris. $146-153$

Pengaruh Model Pembelajaran Explicit Instruction Terhadap Hasil Belajar Siswa Pada Mata Pelajaran Sejarah di Sekolah Menengah Atas Negeri 1 Gelumbang

Ramoni Handayani. 154-161

Pengaruh Penggunaan Media Film Dokumenter Terhadap Hasil Belajar Siswa Pada Mata Pelajaran Sejarah di Sekolah Menengah Atas Sriguna Palembang

Vina Pratiwi. $162-169$ 


\title{
KAJIAN TATA RUANG LUKISAN DINDING PADA BATU BALAI DI DESA TEGUR WANGI LAMA KOTA PAGARALAM SEBAGAI SUMBER PEMBELAJARAN SEJARAH
}

\author{
Muhammad Randi Saputra \\ Guru Sejarah di SMA Negeri 12 Palembang \\ Email: randisaputra817@gmail.com
}

\author{
H. Rudi Asri \\ Dosen Program Studi Pendidikan Sejarah, FKIP Universitas PGRI Palembang \\ Email: rudiasri@gmail.com
}

\begin{abstract}
ABSTRAK
Kota Pagaralam memiliki peninggalan dalam bidang seni, dalam tradisi megalit telah mengenal seni lukis yang berkualitas tinggi, gaya naturalis serta gaya stilir telah muncul di berbagai lukisan tersebut, lukisan tersebut memiliki makna tersendiri yang mengandung nilai-nilai estetika dan juga mencakup pada kehidupan sehari-hari pada masyarakat yang hidup pada zaman itu. Permasalahan dalam penelitian ini adalah bagaimanakah kajian tata ruang lukisan dinding pada batu balai di desa Tegur Wangi Lama kota Pagaralam sebagai sumber pembelajaran sejarah?. Tujuan penelitian mengetahui kajian tata ruang yang terdapat didalam lukisan dinding pada batu balai di desa Tegur Wangi Lama kota Pagaralam sebagai sumber pembelajaran sejarah. Metode yang digunakan dalam penelitian ini adalah metode deskriptif kualitatif. Dari hasil penelitian ini dapat disimpulkan bahwa: 1) Kajian tata ruang lukisan dinding pada batu balai di desa Tegur Wangi Lama menjelaskan tentang keadaan lingkungan dan kondisi yang terdapat pada sekitar lukisan. 2) Makna yang terkandung pada lukisan ini bahwa di daerah tersebut sudah adanya perkampungan dan masyarakatnya melakukan upacara adat pertanian sebagai ungkapan rasa syukur atas hasil pertanian yang mereka dapat. 3) Kajian tata ruang lukisan dinding pada batu balai di desa Tegur Wangi Lama kota Pagaralam dapat dijadikan sebagai sumber pembelajaran sejarah, karena dapat menambah minat siswa dalam belajar sejarah dan dapat menambah wawasan siswa terrhadap peninggalan prasejarah yang ada di Sumatera Selatan.
\end{abstract}

Kata Kunci: Kajian Tata Ruang, Lukikan Dinding Pada Batu Balai, Sumber Pembelajaran Sejarah.

\section{A. PENDAHULUAN}

Provinsi Sumatera Selatan merupakan suatu provinsi yang terletak di pulau Sumatera yang memiliki luas 109.254 kilometer persegi. Bagian daratan provinsi ini berbatasan dengan provinsi Jambi di sebelah Utara, provinsi Lampung di sebelah Selatan, provinsi Bengkulu di sebelah Barat dan sedangkan sebelah Timur dibatasi oleh Selat Karimata dan Laut Jawa yang terletak diantara pulau Belitung dan Kalimantan Barat (Dinas Pariwisata Provinsi Sumatera Selatan, 1994:2).

Apabila merujuk pada masa prasejarah, kita akan dapati informasi tentang asal-usul manusia Sumatera Selatan, ditelusuri mulai dari zaman
Neolithikum dan Megalithikum, sumber ini dapat dilacak dengan adanya benda-benda pada zaman itu di beberapa daerah seperti di kabupaten Lahat dan kota Pagaralam. Daerah ini banyak sekali peninggalan pada masa prasejarah, terutama peninggalan pada masa Megalithikum yang merupakan peninggalan pada masa batu-batu besar seperti menhir, kubur batu, dan dolmen. Penemuan yang banyak ditemukan pada masa Megalithikum yaitu yang berada di Kota Pagaralam dan Kota Lahat (Tim Gemilang, 2015:3).

Kota Pagaralam merupakan salah satu daerah tujuan wisata di Sumatera Selatan dengan keindahan alam dan seni budayanya, hal ini dapat dilihat dari keadaan 
alamnya melalui pemandangan di kaki gunung Dempo. Secara geografis kota Pagaralam terletak pada $4^{\circ}$ lintang Selatan dan $15^{\circ}$ bujur Timur dengan suhu antara $27^{\circ}-30^{\circ}$ Celsius. Kota Pagaralam memiliki luas 63.336 ha yang dimana di sebelah Utara, Timur dan Barat berbatasan dengan kabupaten Lahat dan sebelah Selatan berbatasan dengan provinsi Bengkulu (Dinas Pariwisata Provinsi Sumatera Selatan, 1994:3).

Pagaralam sendiri diambil dari kata Pagar dan Alam yang dapat diartikan sebagai wilayah atau kota yang dipagari oleh alam yaitu dikelilingi oleh gunung Dempo dan Bukit Barisan. Pagaralam merupakan salah satu kota di provinsi Sumatera Selatan yang berjarak kurang lebih $298 \mathrm{~km}$ dari kota Palembang kearah Barat, kota ini memiliki keunikan seperti keindahan alam, kesuburan tanah, keunikan kebudayaan, serta sejumlah peninggalan sejarah purbakala (Dinas Pariwisata Provinsi Sumatera Selatan, 1994:3).

Adapun peninggalan kebudayaan megalitik tersebut berupa bangunanbangunan dari batu-batu besar yang biasanya bentuknya tidak terlalu halus dan juga bentuknya kebanyakan kasar sesuai bentuk yang diperlukan. Perlu diketahui bahwa peninggalan kebudayaan megalitik di Indonesia sangatlah banyak dan masih hidup menjadi kebudayaan sekarang seperti contoh kebudayaan yang terdapat di Toraja, Sulawesi Selatan. Hal ini tentu saja sangat memberikan banyak petunjuk kepada kita bahwa kita harus menyelamatkan kebudayaan tersebut agar tidak hilang oleh zaman, tidak hanya dari hasil kebudayaannya saja, tetapi juga alam pikirannya yang tersimpan dibelakangnya dan menjadi pendorongnya (Soekmono, 1973:72).

Peninggalan megalit yang pernah dilaporkan oleh para peneliti beranggapan bahwa bangunan-bangunan tersebut merupakan peninggalan pada masa Hindu, tetapi pada tahun 1929, van Eerde mengunjungi lokasi penemuan tersebut, van Eerde berbeda pendapat dengan para peneliti terdahulu, ia beranggapan bahwa peninggalan megalit ini tidak adanya pengaruh dari kebudayaan Hindu tetapi masih pada jangkauan zaman prasejarah karena dari bentuk nyatanya pada peninggalan tersebut berupa menhir dan dolmen. Sehingga dapat dibuktikan bahwa peninggalan megalit ini merupakan peninggalan pada masa prasejarah yang tersebar luas di kota Pagaralam (Bedur, 2009:20-22).

Selain peninggalan megalit, kota Pagaralam memiliki peninggalan dalam bidang seni, dalam tradisi megalit telah mengenal seni lukis yang berkualitas tinggi, gaya naturalis serta gaya stilir telah muncul di berbagai lukisan tersebut (Bedur, 2009:28-29).

Lukisan dinding terletak disebuah bukit yang dimana lukisan tersebut berada diatas lereng bukit. Gambar tersebut memiliki makna tersendiri yang mengandung nilai-nilai estetika dan juga mencakup pada kehidupan sehari-hari pada masyarakat yang hidup pada zaman itu. Dari dinamika masyarakat tersebut telah memunculkan adanya pelukis-pelukis yang mempunyai kemampuan yang luar biasa dan berkualitas tinggi yang terdapat di daerah ini (Indriastuti, 2015:130-132).

Perlu diketahui sumber pembelajaran sejarah merupakan seperangkat sarana atau alat yang berisikan materi pokok pembelajaran yang dirancang dan ditulis sesuai kaidah pendidikan yang akan digunakan oleh guru yang membantu untuk menunjang dalam proses pembelajaran di sekolah (Soleh, 2017:176).

Istilah sumber pembelajaran pada umumnya bukan hanya pada perpustakaan dan buku saja, tetapi sumber pembelajaran juga digunakan termasuk juga sebagai sumber pembelajaran (Hamdani, 2011:225).

Dari sumber pembelajaran tersebut guru dapat menjalankan tugasnya sebagai pendidik untuk memberikan materi yang 
telah diberikan sesuai dengan ketentuan yang telah ditetapkan. Sumber pembelajaran juga bukan hanya terdapat didalam buku saja, banyak sekali sumber pembelajaran yang didapatkan, seperti contoh yang terdapat diluar lingkup sekolah, seperti museum contohnya yang memberikan tambahan pembelajaran bagi peserta didik. Salah satu sumber sejarah yang dapat digunakan oleh sebagai sumber pembelajaran sejarah yaitu situs sejarah. Situs sejarah merupakan bukti dari sebuah peradaban pada masa lalu, hal ini dapat dimanfaatkan oleh seorang guru dalam mengajar, khususnya terdapat di daerah masing-masing. Salah satu situs sejarah yang dapat digunakan sebagai sumber pembelajaran sejarah yaitu lukisan dinding pada batu balai yang berada di desa Tegur Wangi Lama yang merupakan peninggalan pada masa prasejarah. Dari lukisan tersebut bahwa peninggalan pada masa prasejarah itu ada, maka itu seorang guru bisa memberikan materi tersebut (Kustono, 2016:22).

Permasalahan dalam penelitian ini adalah bagaimanakah kajian tata ruang lukisan dinding pada batu balai di desa Tegur Wangi Lama kota Pagaralam sebagai sumber pembelajaran sejarah?. Tujuan penelitian mengetahui kajian tata ruang yang terdapat di dalam lukisan dinding pada batu balai di desa Tegur Wangi Lama kota Pagaralam sebagai sumber pembelajaran sejarah.

\section{B. METODE PENELITIAN}

Metode penelitian yang digunakan dalam penelitian ini yaitu penelitian deskriptif kualitatif yang dimana metode deskriptif kualitatif merupakan metode yang berlandaskan pada filsafat postpositivisme yang digunakan untuk meneliti pada kondisi obyek yang alamiah. Dalam penelitian ini pengambilan data dilakukan secara purposive dan snowball, teknik pengumpulan data dengan cara triangulasi data (gabungan), analisis data bersifat induktif dan hasil penelitian kualitatif lebih menekankan makna dari pada generalisasi (Sugiyono, 2010:15).

Penelitian deskriptif kualitatif merupakan jenis penelitian yang temuantemuannya tidak diperoleh dari statistik atau bentuk hitungan lainnya yang bersifat deskriptif dan cenderung menggunakan analisis dengan pendekatan induktif. Metode penelitian deskriptif kualitatif sering disebut dengan metode penelitian naturalistik karena penelitiannya dilakukan secara kondisi yang alamiah karena pada awalnya metode ini lebih banyak digunakan untuk penelitian bidang antropologi budaya, dan juga metode deskriptif kualitatif diuraikan dengan kata-kata menurut peneliti dan akan disimpulkan oleh peneliti (Sugiyono, 2010:16).

Dalam dunia pendidikan, penelitian deskriptif kualitatif mempunyai tempat tersendiri mengingat sifat dan hakikat pendidikan sebagai proses sadar tujuan, dalam meningkatkan kualitas manusia dan kualitas hidupnya sebagai manusia berbudaya (Hadi, 1998:18).

Ada beberapa alasan yang kuat tentang pentingnya penelitian deskriptif kualitatif dalam dunia pendidikan yaitu; Pertama pendidikan sebagai proses sosialisasi pada hakikatnya adalah interaksi manusia dalam lingkungan yang membentuknya melalui proses belajar dalam konteks lingkungan yang berubahubah; Kedua pendidikan senantiasa melibatkan komponen manusia, yakni tenaga pendidikan dan siswa, kurikulum dan sistem pendidikan, lingkungan pendidikan, tempat, ruang dan waktu, serta sarana dan prasarana suatu pendidikan; Ketiga pendidikan sebagai suatu sistem tidak hanya berorientasi pada hasil, etapi juga beroientasi pada proses agar memperoleh hasil yang optimal; Keempat pendidikan dalam pengertian luas terjadi pada manusia dan berlangsung sepanjang hayat, dalam lingkungan keluarga, sekolah, dan lingkungan masyarakat secara alami; 
Kelima, tekanan utama pendidikan adalah pembinaan dan pengembangan kepribadian manusia mencakup aspek intelektual, moral, sosial dalam satu kesatuan utuh, serasi, selaras, dan seimbang, pembinaan dan pengembangan tersebut melalui proses belajar agar diperoleh perubahanperubahan perilaku menyangkut pengetahuan, sikap dan keterampilan (Hadi, 1998:18-19).

\section{HASIL DAN PEMBAHASAN} Gambaran Umum Desa Tegur Wangi

Secara administrasi desa Tegur Wangi termasuk dalam wilayah kelurahan Pagar Wangi, kecamatan Dempo Utara. Secara astronomis desa Tegur Wangi berada pada koordinat 04002'23" LS dan 103012'30" BT dengan ketinggian 875 mdpl. Desa Tegur Wangi berada di sebelah Timur lereng gunung Dempo, sebelah Barat Daya adalah gunung Dempo, di arah Timur Laut adalah Bukit Gumay, dan sebelah Tenggara adalah Bukit Patah (Tim Balai Arkeologi Sumatera Selatan, 2017:6-8).

Desa Tegur Wangi memiliki dua situs bersejarah yaitu situs Tegur Wangi Baru yang merupakan komplek budaya Megalitik yang lengkap seperti Dolmen, Meja Batu, Tetralith, Monolith, dan Pahatan Arca Manusia yang berjarak kurang lebih $6 \mathrm{Km}$ dari pusat kota. Selain situs Tegur Wangi Baru, terdapat juga situs Tegur Wangi Lama yang tedapat sebuah batu berlukis yang terletak diatas bukit, situs ini berada kurang lebih $1 \mathrm{Km}$ dari situs Tegur Wangi Baru.

Maka itu dapat disimpulkan bahwa desa Tegur Wangi merupakan wilayah dari kelurahan Pagar Wangi, kecamatan Dempo Utara. Desa Tegur Wangi berada di sebelah Timur lereng gunung Dempo, sebelah Barat Daya adalah gunung Dempo, Timur Laut adalah Bukit Gumay dan Tenggara adalah Bukit Patah. Desa ini memiliki dua situs peninggalan prasejarah yaitu situs Tegur Wangi Baru yang terdapat hasil kebudayaan pada masa prasejarah seperti Dolmen, Kubur Batu, Meja Batu, Tetralith, dan
Monolith dan situs Tegur Wangi Lama yang terdapat lukisan yang merupakan hasil kebudayaan pada masa prasejarah.

\section{Gambaran Tentang Tata Ruang Pada Lukisan}

Lukisan tersebut merupakan lukisan peninggalan pada masa prasejarah, biasanya masyarakat setempat menyebutnya dengan nama Batu Bersurat. Lukisan ini berada di desa Tegur Wangi, kecamatan Dempo Utara, kota Pagaralam. Dari arah Barat lukisan ini berhadapan dengan sungai dan gunung Dempo, dari Timur berhadapan dengan Bukit Barisan, dari Utara berhadapan dengan sungai dan arah Selatan berhadapan dengan Bukit Barisan. Dari hasil wawancara kepada warga sekitar bahwa lukisan ini berada di lereng bukit yang bernama Bukit Selayar, tetapi Bapak Arman Idris mengatakan bahwa warga sekitar menyebut Bukit Selayar dengan nama Bukit Kayu Manis, karena bukit tersebut banyak ditanami tanaman kayu manis, selain itu juga terdapat aliran sungai yang dimana warga sekitar menyebutnya dengan nama Sungai Selangis.

Untuk menuju lokasi lukisan tersebut melewati jembatan yang terbuat dari bambu, dan juga mengintari rumah warga yang berada di desa tersebut. Lukisan ini berada di lereng bukit yang dimana lereng bukit tersebut merupakan lahan perkebunan kopi milik warga.

Tanaman yang tumbuh disekitar lukisan ini yaitu kopi, pohon johar kandang, petai cina, kayu manis, kedondong cina, durian, tanaman bambang, nangka, alpukat, kemiri, bambu dan pohon nau, dibagian atas lukisan ini ditumbuhi semak belukar, pohon kopi, tumbuhan-tumbuhan paku dan anggrek hutan sumatera.

Lukisan ini berada di ketinggian 800 sampai $900 \mathrm{mdpl}$ dengan kontur tanah berbukit dan jenis tanah humus, di sekitar lukisan tersebut terdapat sebuah gua, gua itu memiliki kedalaman 3 meter dengan 
ketinggian 4 meter. Keberadaan lukisan ini merupakan rangkaian batuan besar karena 5 meter dari lukisan ini terdapat lima buah batu besar yang dimana warga menyebutnya dengan nama Batu Balai karena menurut warga sekitar penamaan Batu Balai memiliki arti yaitu tempat pertemuan para nenek moyang pada zaman dahulu. Lukisan ini merupakan batu endapan dengan tinggi tegak lurus 4,45 meter dengan bidang kemiringan 5,53 meter.

Dari hasil pengukuran gambar manusia membawa nekara tersebut pada bagian kakinya, pada kaki belakang memiliki panjang $140 \mathrm{~cm}$, lebar paha atas pada kaki belakang $50 \mathrm{~cm}$, lebar betis kaki belakang $34 \mathrm{~cm}$ dan lebar pergelangan kaki belakang $21 \mathrm{~cm}$. Dan pengukuran pada kaki depan, panjang pada kaki bagian depan $149 \mathrm{~cm}$, lebar paha atas kaki bagian depan $38 \mathrm{~cm}$, lebar betis kaki depan $32 \mathrm{~cm}$, pergelangan kaki bagian depan $24 \mathrm{~cm}$, panjang sepatu kaki bagian depan $68 \mathrm{~cm}$ dan panjang kaki bagian depan dari dengkul ke kaki $117 \mathrm{~cm}$. Dan pada bagian nekara yang memiliki panjang $103 \mathrm{~cm}$ dan lebar $72 \mathrm{~cm}$. Dengan demikian kesimpulannya yaitu manusia yang membawa nekara ini memiliki bentuk fisik yang tinggi besar, karena terlihat dari ukuran kaki dan ukuran sepatu yang cukup besar sehingga postur tubuh pada manusia tersebut tinggi besar.

Sebelumnya, kondisi dari lukisan ini merupakan semak belukar, menurut warga sekitar kondisi di sekitar lukisan ini merupakan daerah semak belukar, tetapi sekarang kondisinya sudah berbeda karena kondisi di sekitar lukisan ini sudah dijadikan masyarakat setempat menjadi lahan perkebunan kopi sehingga baik warga sekitar maupun para pendatang baik wisatawan maupun para peneliti bisa menuju ke lokasi lukisan itu berada.

Adapun gambar yang terdapat pada lukisan tersebut menurut hasil penelitian arkeologi antara lain: a) Tiga figur manusia dengan posisi kaku, tangan terlentang, muka sederhana tanpa telinga, hidung, ataupun mulut, tinggi pahatan antara 5-10 cm, dari figur tersebut kemungkinan menggambarkan arwah nenek moyang, selain itu adanya pahatan seperti bunga matahari di sebelah di sebelah kiri pahatan figur manusia.

b) Kepala manusia dengan wajah berbentuk lonjong, mata dan mulut dibuat dengan lubang kecil, tetapi tanpa hidung maupun telinga.

c) Figur manusia dengan kepala menghadap ke depan, mata besar melotot, gigi besar, mulut lebar, lehernya juga besar. Figur ini membawa sebuah nekara perunggu yang terikat dengan tali menggantung di punggungnya dan tampak seolaholah membungkuk (Tim Balai Arkeologi Sumatera Selatan, 2017:11).

Sebelum kota Pagaralam masih masuk dalam wilayah kabupaten Lahat lukisan ini sudah ada yang merawatnya, menurut warga sekitar lukisan ini dirawat oleh Karang Taruna dari desa Tegur Wangi, sehingga lukisan ini terawat dengan baik dan juga pihak dari Karang Taruna desa Tegur Wangi membuat petunjuk jalan agar para peneliti ataupun wisatawan yang menuju ke lokasi lukisan tersebut tidak tersesat.

Selain itu juga masyarakat yang tinggal tidak jauh dari lukisan tersebut memiliki mata pencaharian sebagai petani, karena dapat dilihat ketika menuju ke lokasi lukisan yang akan di observasi banyak sekali sawah ataupun ladang yang ada disana, menurut warga sekitar masyarakat di sana setiap bulannya menanam tumbuhan yang berbeda-beda seperti menanam kopi, kacang-kacangan, umbiumbian, bambu, dan tebu. 
Makna Yang Terdapat Pada Lukisan

Pada masa prasejarah, seluruh kebudayaan yang dibuat pasti memiliki makna tersendiri yang terkandung didalamnya, terutama pada lukisan. Lukisan pada masa prasejarah memiliki nilai tensendiri didalamnya yang bertujuan khusus bagi masyarakat yang hidup pada zaman itu. Lukisan dinding pada batu balai di desa Tegur Wangi memiliki makna tersendiri, menurut warga sekitar lukisan ini memiliki makna tersendiri, karena gambar tersebut terdiri dari gambar yang besar dan gambar yang kecil. Gambar yang besar yaitu manusia sedang membawa sebuah tas ransel sedangkan gambar yang kecil yaitu manusia merentangkan tangan, sehingga dapat diambil kesimpulan bahwa gambar yang besar tersebut merupakan seorang raja sedangkan gambar yang kecil merupakan masyarakatnya, jadi inti dari gambar tersebut yaitu bahwa disini sudah ada wilayah atau perkampungan yang sudah dihuni yang dipimpin oleh seorang raja atau kepala suku.

Tetapi menurut pandangan arkeologi bahwa gambar yang besar merupakan gambar manusia yang membawa dua buah nekara, nekara tersebut berada didepan dan dibelakangnya. Menurut ibu Kristantina Indriastuti, nekara ini berasal dari Vietnam yaitu yang memiliki makna yaitu pemanggil hujan dan juga gambar yang kecil merupakan gambar manusia yang merentangkan tangan merupakan seorang yang sedang menari sehingga dapat diambil kesimpulan bahwa gambar ini merupakan kegiatan sehari-hari pada masyarakat yang hidup pada masa itu dan juga merupakan kegiatan upacara pertanian yang dilakukan pada masyarakat yang tinggal di daerah itu, sehingga dari gambar itu menjelaskan tentang kehidupan pertanian mereka, dan juga manusia yang membawa sebuah nekara itu bukanlah seorang kepala suku tetapi merupakan bentuk dari masyarakat yang hidup pada zaman tersebut.
Selain itu juga masyarakat pada masa prasejarah beranggapan bahwa daerah yang tinggi merupakan tempat nenek moyang mereka sehingga sangat wajar jika lukisan tersebut merupakan tempat pemujaan mereka kepada nenek moyang mereka, dan juga bahan untuk membuat lukisan tersebut berada diatas lereng bukit sehingga sangat wajar jika lukisan tersebut berada diatas lereng bukit sehingga makna dari lukisan ini yaitu pada masa prasejarah di wilayah sekitar lukisan ini sudah ada perkampungan yang dipimpin oleh seorang raja atau kepala suku, karakter seorang raja atau kepala suku ini memiliki badan yang besar, kuat dan juga dapat melindungi masyarakatnya sehingga masyarakat yang tinggal di perkampungan itu merasa aman dengan adanya seorang raja atau kepala suku.

Selain itu juga dari gambar ini dapat diambil kesimpulan bahwa di perkampungan itu terdapat sebuah kegiatan adat atau yang disebut dengan upacara adat yang dipimpin oleh seorang raja atau kepala suku, upacara adat ini merupakan upacara adat pertanian yang ada di perkampungan, dari gambar tersebut dapat dilihat bahwa masyarakat di perkampungan itu merasa bahagia karena dari gambar yang dapat dilihat yaitu gambar manusia yang merentangkan tangan tersebut merupakan seorang yang sedang menari-nari.

Dari gambar tersebut menyatakan bahwa masyarakat yang ada di perkampungan itu mengungkapkan rasa syukur mereka atas hasil pertanian mereka yang berlimpah sehingga mereka mengungkapkan rasa syukurnya dengan melakukan upacara adat dengan cara melakukan tari-tarian yang diiringi dengan musik yang dipimpin oleh seorang raja ataupun kepala suku. Selain itu juga mereka beranggapan bahwa lukisan ini merupakan ungkapan rasa syukur mereka kepada nenek moyang dengan hasil panen yang berlimpah sehingga lukisan ini dibuat diatas lereng bukit sebagai tanda bukti bahwa 
mereka tidak melupakan nenek moyang mereka.

Perlu diketahui bahwa dari gambar ini terdapat seorang manusia yang membawa dua buah nekara, nekara tersebut berfungsi sebagai alat pemanggil hujan. Tetapi berbeda yang terdapat pada arca batu gajah yang ditemukan di desa Kotaraya, Pagaralam, arca ini terdapat dua orang prajurit yang masing-masingnya membawa nekara dan juga prajurit yang berada di sebelah kiri gajah itu membawa sebuah pedang.

Berarti dengan adanya nekara yang masing-masing dibawa oleh prajurit yang terdapat pada arca batu gajah tersebut dapat diambil kesimpulan bahwa makna dari nekara ini dapat digunakan sebagai genderang perang, karena dapat dilihat dari prajurit yang berada di sebelah kiri gajah membawa sebuah pedang yang digunakan untuk berperang.

Jadi dapat disimpulkan bahwa di Sumatera Selatan fungsi dari nekara bukan hanya untuk sebagai pemanggil hujan saja, tetapi juga dapat digunakan sebagai genderang perang, karena dapat dilihat dari arca batu gajah yang dimana salah satu dari prajurit yang terdapat pada acra tersebut membawa sebuah pedang, dan juga pedang dapat digunakan sebagai alat untuk berperang sehingga cukup tepat jika nekara yang terdapat pada arca batu gajah digunakan sebagai genderang perang.

Selain di Sumatera Selatan terdapat juga nekara yang berada di daerah lain, fungsi dari nekara bukan hanya sebagai pemanggil hujan dan genderang perang saja, tetapi nekara ini memiliki fungsi lain baik terutama dalam bidang keagamaan maupun dalam bidang sosial-budaya.

Seperti yang ada di wilayah Flores Timur, nekara yang ada wilayah Flores Timur berfungsi dalam bidang keagamaan, yang dimana nekara ini akan digunakan pada saat upacara tertentu dengan menggunakan ritual tertentu, karena mereka menganggap bahwa nekara merupakan tempat nenek moyang mereka sehingga mereka akan menyimpannya dibawah atap rumah dan akan dikeluarkan jika akan digunakan pada saat upacara.

Selain di wilayah Flores Timur, fungsi nekara ini sangat jauh berbeda dengan yang berada di pulau Alor. Di pulau Alor nekara memiliki fungsi dalam bidang sosial-budaya. Masyarakat di pulau Alor menggunakan nekara sebagai mas kawin dalam pernikahan, sehingga masyarakat di pulau Alor beranggapan bahwa nekara merupakan barang yang sangat berharga sehingga mereka beranggapan bahwa semakin besar nekara yang digunakan sebagai mas kawin, maka semakin tinggi harga mas kawin yang digunakannya.

Sehingga dapat disimpulkan bahwa nekara memiliki banyak fungsi sesuai dengan kegunaan dari setiap daerah, bukan hanya untuk memanggil hujan dan genderang perang saja, tetapi dapat digunakan dalam bidang keagamaan maupun dalam bidang sosial-budaya, seperti yang berada di wilayah Flores Timur nekara merupakan tempat nenek moyang mereka, sehingga kegunaan dari nekara ini tidak sembarangan karena jika digunakan sembarangan akan berdampak buruk bagi daerah tersebut.

Selain itu juga terdapat alat yang mirip dengan nekara tetapi bentuknya lebih kecil dan memanjang yang disebut dengan nama moko. Fungsi moko sendiri bermacam-macam, seperti yang terdapat di daerah Kepulauan Manggarai (Flores) yang dimana fungsi moko yaitu sebagai benda pusaka bagi seorang kepala suku dan biasanya moko tersebut akan di wariskan kepada anak laki-laki dari kepala suku itu.

\section{Nilai Sejarah Tata Ruang Lukisan Dinding Pada Batu Balai di Desa Tegur Wangi Lama Kota Pagaralam}

Nilai sejarah adalah kejadian yang terjadi pada masa lampau yang berkaitan dengan kehidupan manusia sesuai yang diinginkan, dicita-citakan dan dianggap 
penting oleh seluruh manusia sebagai anggota masyarakat.

Jadi penjelasan diatas dapat disimpulkan bahwa nilai sejarah merupakan suatu hal yang dipandang secara baik buruknya, maupun benar salahnya yang dapat bermanfaat atau tidaknya mengenai tentang peristiwa yang terjadi pada masa lampau.

Sebagai sumber pembelajaran sejarah di sekolah kajian tata ruang lukisan dinding pada batu balai di desa Tegur Wangi Lama ini terdapat di Kompetensi Inti 3 yang isinya yaitu: Memahami, menerapkan, dan menganalisis tentang faktual, konseptual, prosedural rasa ingin tahunya tentang ilmu pengetahuan, teknologi, seni budaya, dan humaniora dengan wawasan kemanusiaan, kebangsaan, kenegaraan, dan keberadaan terkait fenomena dan kejadian serta menerapkan pengetahuan prosedural pada bidang kajian yang spesifik sesuai dengan bakat dan minatnya untuk memecahkan masalah, dan Kompetensi Dasar 3.4 yang isinya yaitu: Memahami hasil-hasil dan nilainilai budaya masyarakat paraaksara di Indonesia dan pengaruhnya dalam kehidupan lingkungan terdekat, dan juga masuk dalam Kompetensi Dasar 4.4 yang isinya yaitu: Menyajikan hasil-hasil dan nilainilai budaya masyarakat praaksara di Indonesia dan pengaruhnya dalam kehidupan lingkungan terdekat dalam bentuk tulisan. Perlu diketahui bahwa lukisan dinding pada batu balai di desa Tegur Wangi Lama kota Pagaralam ini merupakan hasil peninggalan kebudayaan pada masa prasejarah.

Dalam penggunaan sumber pembelajaran sejarah khususnya tentang kajian tata ruang lukisan dinding pada batu balai di desa Tegur Wangi Lama kota Pagaralam belum pernah dilakukan. Hal ini disebabkan karena terbatasnya sumber bacaan yang membahas tentang lukisan dinding pada batu balai di desa Tegur Wangi kota Pagaralam, jarak tempuh yang cukup jauh dan kesulitan siswa untuk mendapatkan informasi tentang lukisan dinding pada batu balai di desa Tegur Wangi kota Pagaralam karena pembahasan tentang lukisan dinding pada batu balai di desa Tegur Wangi Kota belum masuk dalam buku sumber yang dijadikan pedoman dalam pembelajaran sejarah, sehingga materi kajian tata ruang lukisan dinding pada batu balai di desa Tegur Wangi Lama kota Pagaralam layak dijadikan sebagai sumber pembelajaran sejarah, hal tersebut didasari dengan pentinnya memperkenalkan hasil peninggalan kebudayaan pada masa prasejarah kepada siswa, khususnya peninggalan kebudayaan prasejarah yang ada di Sumatera Selatan.

Dengan adanya pengenalan materi tentang kajian tata ruang lukisan dinding pada batu balai di desa Tegur Wangi Lama kota Pagaralam sebagai sumber pembelajaran sejarah dapat mempermudah tenaga pengajar dalam memperkenalkan hasil peninggalan kebudayaan prasejarah yang ada di Indonesia khususnya di Sumatera Selatan kepada siswa sehingga siswa dapat mengetahui tentang nilai sejarah tata ruang lukisan dinding pada batu balai di desa Tegur Wangi Lama kota Pagaralam.

\section{Sumber Pembelajaran Sejarah Tentang Tata Ruang Lukisan Dinding Pada Batu Balai di Desa Tegur Wangi Lama Kota Pagaralam di Sekolah Menengah Atas}

Perlu diketahui sumber pembelajaran sejarah merupakan seperangkat sarana atau alat yang berisikan materi pokok pembelajaran yang dirancang dan ditulis sesuai kaidah pendidikan yang akan digunakan oleh guru yang membantu untuk menunjang dalam proses pembelajaran di sekolah (Soleh, 2017:176).

Jadi sumber pembelajaran sejarah merupakan alat yang berisikan tentang materi-materi tentang sejarah yang digunakan oleh guru untuk membantu proses pembelajaran yang dilaksanakan di 


\section{Kalpataru, Volume 4, Nomor 2, Desember 2018 (89-98)}

sekolah yang harus sesuai dengan kurikulum yang berlaku di sekolah.

Menurut guru di sekolah menengah atas, ada beberapa faktor penggunaan sumber pembelajaran yang baik seperti sumber belajar yang memadai, sarana dan prasarana yang baik, dan tata cara guru dalam menyampaikan materi cukup baik. Peran guru dalam menyampaikan pembelajaran sangat penting, karena sumber pembelajaran yang disampaikan harus berkaitan dengan materi yang akan disampaikan, jadi peran guru sangatlah penting karena seorang guru diwajibkan untuk menguasai materi yang akan disampaikan kepada siswa sehingga dengan penyampaian materi yang cukup baik akan memberikan dampak yang bagus untuk siswa dalam memahami materi yang disampaikan.

Dalam memahami materi pelajaran yang akan disampaikan kepada siswa, seorang guru harus membaca dan membuat ringkasan materi yang akan disampaikan kepada siswa sehingga dengan membaca dan membuat ringkasan akan mempermudah guru untuk menyampaikan materi yang akan disampaikan, selain itu juga dapat menambah pengetahuan dan bahan ajar yang akan disampaikan.

Menurut guru di sekolah menengah atas tersebut, mengatakan bahwa modul pembelajaran yang dibuat oleh peneliti sudah baik karena dilengkapi dengan gambar, buku, dan jurnal yang sudah lengkap, selain itu juga peneliti menambahkan hasil wawancara dan hasil observasi didalam modul tersebut sehingga dapat menarik guru untuk memberikan materi tersebut dan juga dapat menarik siswa untuk belajar.

Sehingga dengan adanya modul tersebut dapat dijadikan sebagai referensi tambahan untuk sumber pembelajaran sejarah khususnya pada materi hasil kebudayaan masa prasejarah yang ada di Indonesia terutama yang terdapat di provinsi Sumatera Selatan. Selain menambah sumber pemebalajaran sejarah modul tersebut dapat menambah minat siswa dalam belajar sejarah dan juga siswa mengetahui peninggalan-peninggalan prasejarah yang ada di provinsi Sumatera Selatan

\section{SIMPULAN}

Kajian tata ruang pada lukisan dinding ini yaitu bahwa lukisan dinding ini merupakan lukisan peninggalan pada masa prasejarah, lukisan ini berada di desa Tegur Wangi, kecamatan Dempo Utara, kota Pagaralam. Dari arah Barat lukisan ini berhadapan dengan sungai dan gunung Dempo, dari Timur berhadapan dengan Bukit Barisan, dari Utara berhadapan dengan sungai dan arah Selatan berhadapan dengan Bukit Barisan. Untuk menuju lokasi lukisan tersebut melewati jembatan yang terbuat dari bambu, dan juga mengintari rumah warga yang berada di desa tersebut. Lukisan tersebut berada lereng bukit yang dimana lereng bukit tersebut merupakan lahan perkebunan kopi milik warga. Banyak sekali tanaman yang tumbuh disekitar lukisan tersebut dan di atasnya terdapat ditumbuhi semak belukar. Lukisan tersebut merupakan gambar manusia yang membawa dua buah nekara, gambar bunga yang ditengahnya terdapat gambar wajah manusia, manusia merentangkan tangan dan juga terdapat garis-garis simetris.

Makna dari lukisan ini yaitu pada masa prasejarah di wilayah sekitar lukisan ini sudah ada perkampungan yang dipimpin oleh seorang raja atau kepala suku, selain itu juga dari gambar ini bahwa di perkampungan itu terdapat sebuah upacara adat yang dipimpin oleh seorang raja atau kepala suku upacara adat ini merupakan upacara adat pertanian yang ada di perkampungan, dari gambar tersebut dapat dilihat bahwa masyarakat di perkampungan itu merasa bahagia karena dari gambar yang dapat dilihat yaitu gambar manusia yang merentangkan tangan tersebut 
merupakan seorang yang sedang menarinari. Perlu diketahui bahwa dari gambar ini terdapat seorang manusia yang membawa dua buah nekara, nekara tersebut berfungsi sebagai alat pemanggil hujan, sehingga dapat disimpulkan bahwa masyarakat pada perkampungan ini mengadakan upacara adat pertanian.

Kajian tata ruang lukisan dinding pada batu balai di desa Tegur Wangi Lama kota Pagaralam dapat dijadikan sebagai sumber pembelajaran sejarah di sekolah menengah atas, karena kajian tata ruang lukisan dinding pada batu balai di desa Tegur Wangi Lama kota Pagaralam belum diterapkan oleh guru sejarah sebagai sumber pembelajaran sejarah. Dengan adanya pengenalan materi ini, diharapkan dapat menambah pengetahuan dan mempermudah guru untuk memperkenalkan hasil kebudayaan pada masa praaksara yang ada di kota Pagaralam.

\section{DAFTAR PUSTAKA}

Bedur, Marzuki, dkk. 2009. Sejarah Besemah (Dari Zaman Megalitikum, Lampik Empat Merdike Due, Sindang Merdike ke Kota Perjuangan). Palembang: Rambang.

Dinas Pariwisata Provinsi Sumatera Selatan. 1994. Welcome to South Sumatera, Palembang. Palembang: Dinas Pariwisata Provinsi Sumatera Selatan.

Hadi, Amirul dan Haryono. 1998. Metodologi Penelitian Pendidikan. Bandung: Pustaka Setia.

Hamdani. 2011. Strategi Belajar Mengajar. Bandung: Pustaka Setia.

Indriastuti Kristantina. 2015. "Seni Lukis dan Seni Gores Pada Megalitik Pasemah Provinsi Sumatera Selatan". Dalam Siddhayatra. Volume 20, Nomor 20, November 2015. (129-141).

Kustono dan Firmansyah. 2016. "Eksistensi Istana Kerajaan di Kalimantan Barat Sebagai Sumber Pembelajatan
Sejarah". Dalam Historia. Volume 4, 2016. (19-29).

Soekmono. 1973. Pengantar Sejarah

Kebudayaan Indonesia 1.

Yogyakarta: Kanisius.

Soleh, Kabib. 2017. "Prasasti Talang Tuo Peninggalan Kerajaan Sriwijaya Sebagai Materi Ajar Sejarah di Sekolah Menengah Atas". Dalam Historia. Volume 5, 2017. (173-192).

Sugiyono. 2010. Metode Penelitian Pendidikan (Pendekatan Kuantitatif, Kualitatif, dan R\&D). Bandung: Alfabeta.

Tim Balai Arkeologi Sumatera Selatan. 2017. Penelitian Permukiman Megalitik Situs Tegur Wangi Kota Pagaralam, Palembang: Balai Arkeologi Sumatera Selatan.

Tim Gemilang. 2015. Sejarah Kerajaan Di Sumatera Selatan (Napak Tilas Kerajaan Terbesar dan Terkuat di Bumi Sriwijaya). Palembang: Tim Gemilang. 


\section{KETENTUAN PENULISAN ARTIKEL JURNAL KALPATARU}

1. Naskah berbahasa Indonesia yang disempurnakan bertemakan kesejarah yang meliputi hasil penelitian sejarah, pengajaran sejarah dan penelitian kebudayaan.

2. Naskah harus asli dan belum pernah dimuat dalam media lain. Naskah dapat berupa hasil penelitian/artikel kajian konseptual yang ditulis oleh perorangan dan atau kelompok.

3. Naskah ditulis dengan cara-cara yang sesuai dengan ketentuan penulisan artikel ilmiah menggunakan bahasa Indonesia yang baku, berupa ketikan, beserta soft file dalam CD-RW atau dengan mengirimkan email pada redaksi jurnal Kalpataru dengan alamat jurnalkalpatarusejarah@gmail.com, spasi tunggal, jenis huruf arial narrow ukuran 12, dengan panjang naskah antara 8-15 halaman pada kertas A4.

4. Artikel hasil penelitian memuat:

JUDUL

Nama Penulis

Abstrak

A. PENDAHULUAN

B. METODE PENELITIAN

C. HASIL DAN PEMBAHASAN

D. SIMPULAN

DAFTAR PUSTAKA
: XXX (HURUF KAPITAL)

: (disertai jabatan, institusi, dan email)

: (Bahasa Indonesia yang memuat 100-200 kata diikuti kata kunci, dengan jenis huruf arrial narrow dan ukuran huruf 11 serta dicetak miring).

: (memuat latar belakang masalah, tinjauan pustaka secara ringkas, masalah penelitian, dan tujuan penelitian).

: (berisi simpulan).

: (berisi pustaka yang dirujuk dalam uraian naskah).

5. Artikel Kajian Konseptual memuat:

\section{JUDUL \\ Nama Penulis \\ Abstrak \\ PENDAHULUAN \\ Sub Judul \\ Simpulan \\ DAFTAR PUSTAKA}

: XXX (HURUF KAPITAL)

: (disertai jabatan, institusi, dan email)

: (Bahasa Indonesia yang memuat 100-200 kata diikuti kata kunci, dengan jenis huruf arrial narrow dan ukuran huruf 11 serta dicetak miring.

: (memuat latar belakang masalah, tinjauan pustaka secara ringkas, masalah penelitian, dan tujuan penelitian).

: Sesuai dengan kebutuhan (tanpa numbering).

: (berisi simpulan dan saran).

6. Referensi sumber dalam teks artikel ditulis dengan menggunakan side note, contoh (Jalaludin, 1991:79); sementara penulisan daftar pustaka disusun dengan ketentuan. Nama pengarang. Tahun terbit. Judul (dicetak miring). Kota terbit: Nama Penerbit. Contoh: Koentjaraningrat. 2010. Manusia dan Kebudayaan di Indonesia. Jakarta: Djambatan. Daftar pustaka hanya memuat pustaka/sumber yang dirujuk dalam uraian dan disusun menurut abjad tanpa nomor urut.

7. Naskah yang dimuat akan disunting kembali oleh redaksi tanpa mengubah isinya.

8. Naskah yang ditolak (tidak bisa dimuat) akan dikirim kembali ke penulis dengan pemberitahuan tertulis dari redaksi atau melalui email.

9. Penulis yang naskahnya dimuat akan mendapat 1 (satu) majalah nomor yang bersangkutan.

10. Kontak person: Muhamad Idris (081271498618); Eva Dina Chairunisa (082281267851); Jeki Sepriady (085269261780). 